\title{
Associations of Single Nucleotide Polymorphism rs 17782313 in Melanocortin 4 Receptor Gene with Anthropometric Indices in Normal and Obesity Primary School Children in Hanoi
}

\author{
Le Thi Tuyet ${ }^{1,}$, Tran Quang Binh ${ }^{2}$ \\ ${ }^{1}$ Hanoi National University of Education, 136 Xuan Thuy, Cau Giay, Hanoi, Vietnam \\ ${ }^{2}$ National Institute of Nutrition, 48B Tang Bat Ho, Hanoi, Vietnam \\ Received 04 February 2018 \\ Revised 11 May 2018; Accepted 25 December 2018
}

\begin{abstract}
Melanocortin-4 receptor (MC4R) plays an important role in regulating food intake and energy balance. A number of studies have revealed that variant rs17782313 is significantly associated with obesity in different populations. However, its role to obesity in the Vietnamese populations has not been identified. This study aims to evaluate the association of rs17782313 with anthropometric indices and obesity in a group of Vietnamese children. A case-control study was conducted on 559 children aged 6-11 years (278 obese cases and 281 normal controls). The nutrition status of the children was classified using both the criteria of the International Obesity Task Force 2000 and those of the World Health Organization 2007. The results show that in the normal group, the data of $\mathrm{z}$ score of weight for age was the highest in CC genotype group and was the lowest in TT genotype group ( 0.11 and -0.38 , respectively, $p=0.023)$. In the obese group, the waist hip ratio was the lowest in TT genotype group and the highest one was in CC genotype group ( 0.93 and 0.97 respectively, $p=0.031$ ). The study findings indicate that variant rs 17782313 of MC4R is likely to have an impact on the changing of weight and central obesity in the Vietnamese children.
\end{abstract}

Keywords: rs17782313, MC4R, obesity, anthropometric indices, Vietnamese children

\section{Introduction}

Obesity is a complex disease that involves interactions between environmental and genetic factors in its pathogenesis [1]. Recent advances in genome wide association studies (GWAs)

\footnotetext{
${ }^{*}$ Corresponding author. Tel.: 84- 968795555.

Email: tuyetlt@hnue.edu.vn

https:// doi.org/10.25073/2588-1132/vnumps.4107
}

have evidenced the association of common variants of several genes with obesty and other measurements of obesity [2, 3]. Among these genes, the melanocortin-4 receptor $(M C 4 R)$ gene has been considered to confer obesity risk $[4,5]$.

$M C 4 R$ gene $(18 \mathrm{q} 22)$ is a 322 -amino acid; which belongs to the family of seventransmembrane, G-protein-linked receptor involved in central regulation of energy 
homeostasis, such as hypothalamus, brainstem, and other brain dopamine-rich regions [6-8]. Therefore, this protein has role in regulation food intake and energy balance [8].

Common variation in or near $M C 4 R$ gene was reported as the association signal for obesity in many studies [9]. In this sense, the single nucleotide polymorphism (SNP) rs17782313, mapped $188 \mathrm{~kb}$ downstream from $M C 4 R$, has been reported association with obesity and body mass index (BMI) and some anthropometric indeces in adults and children $[9,10]$. However, some studies did not find the association of this SNP with dietary intake, obesity and BMI $[11,12]$.

Until now, there has been paucity of published data on the association of MC4R gene with obesity and anthropometric indices among Vietnamese children. Therefore, the study aimed to investigate the association between MC4R rs17782313 polymorphism and obesity, anthropometric indices in Hanoi primary school children.

\section{Subjects and methods}

\subsection{Subjects of study}

A case-control study was conducted with a total of 559 subjects (278 obese cases and 281 normal controls) recruited from a crosssectional population-based study. First, 7750 children aged 6-11 years in 31 Hanoi primary schools were recruited randomly between October and December 2011 in 5 urban and 3 suburban districts of Hanoi. These children were measured anthropometric indices and were then classified into 4 groups, including underweight-, normal weight-, overweight-, and obese- groups. For genetic analysis, $2 \mathrm{ml}$ of venous blood was collected from 281 normal children and 278 obese children. The blood was stored in an EDTA (ethylene diamine tetraacetic acid) tube and then stored at $-80^{\circ} \mathrm{C}$.

Written consent to participate in the study was given by the parents of all subjects. The
Ethics Committee of the National Institute of Nutrition approved this study No. 12-01/HĐĐĐ in 2011 [13].

\subsection{Measurements}

Anthropometric indices including weight, height, waist circumference (WC), and hip circumference (HC) were measured twice for each individual, and the mean was used for the purpose of analysis. Body weight and height were measured with subjects in light clothing and without shoes. BMI was calculated as the body weight per square of the height $\left(\mathrm{kg} / \mathrm{m}^{2}\right)$. WC was measured midway between the lower rib margin and the iliac crest, while $\mathrm{HC}$ was measured at the broadest circumference below the waist. Waist-hip ratio (WHR) was calculated as the WC $(\mathrm{cm})$ divided by the $\mathrm{HC}(\mathrm{cm})$.

Obesity children and normal weight children were classified using the criteria of age- and sex-specific BMI cut-off points proposed by the International Obesity Task Force (IOTF, 2000). Children who were classified either underweight or stunting or wasting by the criteria of World Health Organization (WHO, 2007) were excluded from the study. In addition, children who were obese due to medical reasons were also excluded. In the obese group, there were not any children who were obese due to Cushing's syndrome or who were using medications, which can cause increased body weight (such as steroids, some antidepressants).

\subsection{Genotyping}

Genomic DNA was extracted from peripheral blood leukocytes by using the Wizard ${ }^{\circledR}$ Genomic DNA Purification Kit (PR omega Corporation, USA). Genotyping of MC4R rs17782313 was carried out by using the polymerase chain reaction-restriction fragment length polymorphism (PCR-RFLP) method [14]. Genetic analysis processing was performed in the Molecular Genetic Laboratory, National Institute of Hygiene and Epidemiology. 


\subsection{Statistics}

The sample size for a case control study was calculated by using QUANTO software. Categorical variables (i.e gender or living region) were represented as percentages and differences between control and obese group were tested by the $\chi^{2}$ test. Quantitative variables firstly were checked whethere data is normal distribution or not by Nonparametric test. Subsequently, independent-sample $t$ test and Mann-Whitney U test were used to statistical analysis for normal distribution variables and the other variables, respectively. Using ANOVA test to compare of more than two groups. The above statistical procedures were performed using SPSS version 16.0 (SPSS, Chicago, USA).

\section{Results}

\subsection{Characteristics of participants in control and obese groups}

The characteristics of subjects in cases and controls are shown in Table 1. There were significant differences between obesity and control groups with regards to living region, birth weight, height, weight, BMI, WC, HC, and WHR.

Table 2 shows the frequencies of the TT, $\mathrm{CT}$ and $\mathrm{CC}$ genotypes in case and control groups. There were not significant differences between obesity and control groups in frequencies of genotype and allele of SNP rs17782313 $(p>0.05)$. Allele $\mathrm{C}$ was the minor allele.

\subsection{Anthropometric indices of subjects in the MC4R-rs17782313 genotypes}

The anthropometric indices in the different $M C 4 R$-rs17782313 genotypes of normal group and case group were showed in table 3 and table 4, respectively. The results showed that birth weight, height, weight, BMI, z-score BMI for age, waist circumference, hip circumference were not significantly different between genotypes of rs 17782313 in both normal weight and obesity children. However, in normal group, the data of z-score height for age and z-score weight for age was highest in CC genotype group and was lowest in TT genotype group $(p<0.05)$. In obese group, the wast hip ratio index was lowest in TT genotype group and the highest one was in $\mathrm{CC}$ genotype group $(p<0.05)$

Table 1. Characteristics of participants in control and obese groups

\begin{tabular}{llll}
\hline Characteristics & Control group $(\mathrm{n}=281)$ & Obese group $(\mathrm{n}=278)$ & $p$-value \\
\hline Boy $(\%)$ & 62.2 & 71.9 & 0.084 \\
Age (year) & $8.1 \pm 1.4$ & $8.0 \pm 1.3$ & 0.337 \\
Urban region $(\%)$ & 52.3 & 61.9 & 0.014 \\
Birth weight $(\mathrm{g})$ & $3178(2900-3500)$ & $3320(3000-3600)$ & $0.001^{\mathrm{a}}$ \\
Height $(\mathrm{cm})$ & $125.5 \pm 9.0$ & $130.0 \pm 8.7$ & $<0.0001$ \\
Weight $(\mathrm{kg})$ & $23.8(20.8-27.4)$ & $38.8(34.2-45.7)$ & $<0.0001^{\mathrm{a}}$ \\
BMI $\left(\mathrm{kg} / \mathrm{m}^{2}\right)$ & $15.21(14.5-16.3)$ & $23.45(21.9-25.1)$ & $<0.0001^{\mathrm{a}}$ \\
WC $(\mathrm{cm})$ & $52.7(49.5-55.5)$ & $72.1(68.3-77.9)$ & $<0.0001^{\mathrm{a}}$ \\
HC $(\mathrm{cm})$ & $62.2(61.4-63.0)$ & $77.9(77.0-78.8)$ & $<0.0001^{\mathrm{b}}$ \\
WHR & $0.86 \pm 0.06$ & $0.94 \pm 0.05$ & $<0.0001$ \\
\hline
\end{tabular}

BMI, body mass index; WC, waist circumference; HC, hip circumference, WHR, waist-hip ratio. Data are the mean $\pm S D$ unless otherwise indicated.

${ }^{a}$ Data are median (interquartile range).

${ }^{b}$ Data are geometric mean (95CI).

p-value by Student t test or Mann-Whitney U test or Chi-square test. 
Table 2. Distribution of the $M C 4 R$-rs17782313 genotype in control and obese groups

\begin{tabular}{llll}
\hline & $\begin{array}{l}\text { Normal group } \\
(\mathrm{n}=280)\end{array}$ & $\begin{array}{l}\text { Obese group } \\
(\mathrm{n}=277)\end{array}$ & $p$-value \\
\hline Genotype & & $241(87.0)$ & 0.754 \\
TT & $242(86.4)$ & $31(11.2)$ & \\
CT & $29(10.4)$ & $5(1.8)$ & \\
CC & $9(3.2)$ & & 0.407 \\
Allele & & $513(92.6)$ & \\
T & $513(91.6)$ & $41(7.4)$ & \\
C & $47(8.4)$ & & \\
\hline
\end{tabular}

Data are $n(\%)$. p-value obtained by Chi-square test.

Table 3. Anthropometric indices of normal group in the different $M C 4 R$-rs 17782313 genotypes

\begin{tabular}{lllll}
\hline Characteristics & TT $(\mathbf{n = 2 4 2})$ & CT $(\mathbf{n = 2 9})$ & CC (n=9) & $\boldsymbol{p}$ \\
\hline Birth weight $(\mathrm{g})$ & $3200(2950-3400)$ & $3200(2950-3400)$ & $3200(2950-3400)$ & $0.593^{\mathrm{a}}$ \\
Height $(\mathrm{cm})$ & $125.6 \pm 8.8$ & $124.3 \pm 10.3$ & $127.4 \pm 10.3$ & 0.632 \\
Z score height for age & $-0.29 \pm 0.79$ & $-0.58 \pm 0.69$ & $0.09 \pm 1.05$ & $\mathbf{0 . 0 5 3}$ \\
Weight (kg) & $24.2(23.6-24.8)$ & $23.4(21.4-25.6)$ & $25.8(22.2-24.7)$ & $0.421^{\mathrm{b}}$ \\
Z score weight for age & $-0.38 \pm 0.74$ & $-0.66 \pm 0.68$ & $0.11 \pm 0.87$ & $\mathbf{0 . 0 2 3}$ \\
BMI $\left(\mathrm{kg} / \mathrm{m}^{2}\right)$ & $15.5 \pm 1.3$ & $15.3 \pm 1.5$ & $16.0 \pm 1.2$ & 0.378 \\
Z score BMI for age & $-0.30 \pm 0.74$ & $-0.43 \pm 0.85$ & $0.09 \pm 0.71$ & 0.191 \\
WC $(\mathrm{cm})$ & $53.2(52.6-54.8)$ & $53.4(50.7-56.2)$ & $59.6(50.7-63.8)$ & $0.166^{\mathrm{b}}$ \\
HC $(\mathrm{cm})$ & $62.5 \pm 5.8$ & $62.8 \pm 5.5$ & $65.1 \pm 7.0$ & 0.482 \\
WHR & $0.86 \pm 0.06$ & $0.85 \pm 0.07$ & $0.88 \pm 0.04$ & 0.529 \\
\hline
\end{tabular}

p-value by ANOVA test. Data are the mean \pm SD unless otherwise indicated.

${ }^{a}$ Data are median (interquartile range).

${ }^{b}$ Data are geometric mean (95CI).

Table 4. Anthropometric indices of obese group in the different MC4R-rs17782313 genotypes

\begin{tabular}{lllll}
\hline Characteristics & TT $(\mathbf{n}=\mathbf{2 4 1})$ & CT (n=31) & CC (n=5) & $\boldsymbol{p}$ \\
\hline Birth weight $(\mathrm{g})$ & $3332 \pm 447$ & $3213 \pm 506$ & $3520 \pm 526$ & 0.261 \\
Height $(\mathrm{cm})$ & $129.9 \pm 8.5$ & $129.9 \pm 10.0$ & $136.2 \pm 12.4$ & 0.632 \\
Z score height for age & $0.56 \pm 0.96$ & $0.64 \pm 1.07$ & $1.03 \pm 1.32$ & 0.542 \\
Weight $(\mathrm{kg})$ & $40.2 \pm 7.8$ & $40.8 \pm 9.2$ & $45.4 \pm 12.4$ & 0.332 \\
Z score weight for age & $2.70 \pm 0.71$ & $2.70 \pm 0.73$ & $1.99 \pm 0.18$ & 0.370 \\
BMI $\left(\mathrm{kg} / \mathrm{m}^{2}\right)$ & $23.5 \pm 2.1$ & $23.9 \pm 2.2$ & $24.0 \pm 3.0$ & 0.710 \\
Z score BMI for age & $2.99(2.69-3.33)$ & $3.06(2.71-3.33)$ & $2.59(2.52-3.89)$ & $0.214^{\mathrm{a}}$ \\
WC $(\mathrm{cm})$ & $72.9 \pm 6.8$ & $74.5 \pm 7.6$ & $75.7 \pm 8.8$ & 0.334 \\
HC $(\mathrm{cm})$ & $78.0 \pm 6.2$ & $78.1 \pm 6.3$ & $78.3 \pm 9.8$ & 0.994 \\
WHR & $0.93 \pm 0.05$ & $0.96 \pm 0.04$ & $0.97 \pm 0.02$ & $\mathbf{0 . 0 3 1}$ \\
\hline
\end{tabular}

BMI, body mass index; WC, waist circumference; HC, hip circumference, WHR, waist-hip ratio.

Data are the mean $\pm S D$ unless otherwise indicated.

${ }^{a}$ Data are median (interquartile range).

p-value by ANOVA test. 


\subsection{Associations of rs 17782313 with obesity in Hanoi primary school children}

The analysis of the associations of rs17782313 polymorphism with obesity among genetic modes of inheritance (dominant, codominant, overdominant, recessive and additive) showed that this study did not find the relatation between rs 17782313 polymorphism with obesity in Hanoi primary school children in both Univariate and multivariate logistic regression analyses (table 5).

Table 5. Associations of rs17782313 with obesity in Hanoi primary school children

\begin{tabular}{|c|c|c|c|c|}
\hline \multirow[t]{2}{*}{ Genetic model } & \multicolumn{2}{|c|}{$\begin{array}{l}\text { Univariate logistic regression } \\
\text { analyses }\end{array}$} & \multicolumn{2}{|c|}{$\begin{array}{l}\text { Multivariate logistic regression } \\
\text { analyses }\end{array}$} \\
\hline & OR $(95 \% \mathrm{CI})$ & $p$ & OR* $(95 \% \mathrm{CI})$ & $p^{*}$ \\
\hline \multicolumn{5}{|l|}{ Dominant } \\
\hline TT & 1 & & 1 & \\
\hline $\mathrm{CT}+\mathrm{CC}$ & $1.0(0.6-1.6)$ & 0.842 & $0.98(0.59-1.63)$ & 0.928 \\
\hline \multicolumn{5}{|l|}{ Codominant } \\
\hline $\mathrm{TT}$ & 1 & & 1 & \\
\hline $\mathrm{CT}$ & $1.1(0.6-1.8)$ & 0.796 & $1.12(0.64-1.96)$ & 0.696 \\
\hline $\mathrm{CC}$ & $0.6(0.2-1.7)$ & 0.302 & $0.546(0.17-1.7)$ & 0.290 \\
\hline \multicolumn{5}{|l|}{ Overdominant } \\
\hline $\mathrm{TT}+\mathrm{CC}$ & 1 & & 1 & \\
\hline $\mathrm{CT}$ & $1.1(0.6-1.9)$ & 0.751 & $1.14(0.65-1.98)$ & 0.656 \\
\hline \multicolumn{5}{|l|}{ Recessive } \\
\hline $\mathrm{TT}+\mathrm{CT}$ & 1 & & 1 & \\
\hline $\mathrm{CC}$ & $0.6(0.2-1.7)$ & 0.779 & $0.53(0.17-1.68)$ & 0.281 \\
\hline Additive (per allele C) & $0.9(0.6-1.3)$ & 0.585 & $0.91(0.6-1.36)$ & 0.640 \\
\hline
\end{tabular}

* values were adjusted by sex, age, birthweight and living region

\section{Discussion}

The MC4R transduces its signal by integrating a satiety signal provided by its agonist $\alpha$ - melanocyte-stimulating hormone ( $\alpha$ $\mathrm{MSH}$ ) and an orexigenic signal provided by its antagonist agouti-related protein (AGRP). These ligands are expressed in the hypothalamus and are regulated by the adipocyte-secreted hormone, leptin, to control food intake and maintain long-term energy homeostasis [6-8]. Thus, the $M C 4 R$ gene has been considered as a genetic factor related to human obesity [8].

Recently, GWAs demonstrated $M C 4 R$ to be one of the genes, which associates with common obesity [4, 5]. The common polymorphism rs17782313 has recently been found to be unequivocally associated with obesity-related phenotypes in adults and children in different ethnicity and age groups $[9,10,15]$.

However, the associations of rs 17782313 with obesity and anthropometric indices are not consistent in many populations. For examle, in Chinese population, despite some studies showed evidence of the significant association such as the study by Huang et al [16] in adults; Lv D et al [17] in children, studies by Tao et al [18] in adults, Wang et al [19] in children revealed non-significant association.

In this study, we found that Vietnamese normal children (6-11 years old) carrying the $\mathrm{CC}$ genotype have highest $\mathrm{z}$ score of weight for age in comparation with ones who carried CT and TT genotypes $(P=0.023)$. In obese group, children who carried CC genotype showed highest data in waist hip ratio while children whose TT genotype showed the lowest in that data $(p=0.031)$. This study also did not find the 
association between rs17782313 with obesity among genetic modes of inheritance $(p>0.05)$. This result may be due to the small sample size. Our data suggested that the association between MC4R variant and the change of weight and the central obesity in Vietnamese primary school children.

The major strengths of our study are that it has been the first data of the relation between SNP rs17782313 near MC4R gene with some anthropometric indices in Vietnamese people. However, several limitations need to be acknowledged. First, the case-control design did not allow a causal conclusion. Second, small sample size is also a possible reason leading to the not significantly association between rs17782313 and obesity in the cohort. Next, we were unable to collect information regarding the food intake and physical activity levels of the participants, so the relationship between those two factors toward obesity could not be evaluated in the study.

Due to the percentage of children who are overweight and obesity has been increasing in Vietnam, the study of the relationship between genetic, environmemtal, gene-environmental interaction factors and obesity is nescessary.

\section{Conclusion}

This study showed the significant different of MC4R rs17782313 polymorphism genotypes in Z-score of weight for age and weight hip ratio in primary school children in Vietnam. It is necessary to extend the scale of the research and collect more information on both genetic and environmental factors to identify the geneenvironment interactions to childhood obesity in Vietnam.

\section{Acknowledgements}

We thank colleagues in Hanoi National University of Education and National Institute of Nutrition for their kindly help and support. This study was supported by the grant no. B2018-YD01 from the Ministry of Education and Training, and the grant no. 01C-08/052011-2 from Hanoi Department of Science and Technology, Vietnam.

\section{References}

[1] C.H. Andreasen, G. Andersen, Gene environment interactions and obesity - Further aspects of genome wide association studies, Nutrition 25(10), (2009), 998.

[2] T. Fall, E. Ingelsson, Genome-wide association studies of obesity and metabolic syndrome, Mol Cell Endocrinol, 382(1), (2012), 740.

[3] Y. Lu, R.J. Loos, Obesity genomics: assessing the transferability of susceptibility loci across diverse populations, Genome Med, 5(6), (2013), 55.

[4] C. Cyrus, M.H. Ismail, S. Chathoth, et al., Analysis of the impact of common polymorphisms of the FTO and MC4R Genes with the risk of severe obesity in Saudi Arabian population, Genet Test Mol Biomarkers, 22(3), (2018), 170.

[5] A.M. de Carvalho, P. Shao, H. Liu et al., The MC4R genotype is associated with postpartum weight reduction and glycemic changes among women with prior gestational diabetes: longitudinal analysis. Sci Rep 7(1), (2017), 9654.

[6] N. Balthasar, L.T. Dalgaard, C.E. Lee et al., Divergence of melanocortin pathways in the control of food intake and energy expenditure. Cell, 123(3), (2005), 493.

[7] R.D. Cone, Anatomy and regulation of the central melanocortin system, Nat Neurosci 8(5), (2005), 571.

[8] J.F. Davis, D.L. Choi, J.D. Shurdak et al., Central melanocortins modulate mesocorticolimbic activity and food seeking behavior in the rat. Physiol Behav 102(5), (2011), 491.

[9] V. Turcot, Y. Lu, H.M. Highland et al., Publisher Correction: Protein-altering variants associated with body mass index implicate pathways that control energy intake and expenditure in obesity. Nat Genet (2018).

[10] C.M.M. Resende, D.F. Durso, K.B.G. Borges et al., The polymorphism rs17782313 near MC4R gene is related with anthropometric changes in 
women submitted to bariatric surgery over 60 months. Clin Nutr. 5614(17), (2017), 30179-6.

[11] A.L. Hasselbalch, L. Angquist, L. Christiansen et al., A variant in the fat mass and obesityassociated gene (FTO) and variants near the melanocortin-4 receptor gene (MC4R) do not influence dietary intake, J Nutr. 140(4), (2010), 831.

[12] S.F. Grant, J. P. Bradfield, H. Zhang H, et al., Investigation of the locus near MC4R with childhood obesity in Americans of European and African ancestry. Obesity (Silver Spring). 17(7), (2009), 1461.

[13] L.T. Tuyet, B.T. Nhung, D.T.A. Dao, et al., The brain-derived neurotrophic factor val66met polymorphism, delivery method, birth weight, and night sleep duration as determinants of obesity in Vietnamese children of primary school age, Childhood Obesity, (2017), DOI: 10.1089/chi.2017.0007.

[14] Lê Thị Tuyết, Trần Quang Bình, Bước đầu nghiên cứu đa hình nucleotide đơn MC4R-rs17782313 ở trẻ 5-6 tuổi Hà Nội bằng phương pháp PCR-RFLP, Tạp chí Khoa học Đại học Quốc gia Hà Nội, chuyên san KHTN và Công nghệ, 31 (3), (2015), 57.
[15] R.J. Loos, C.M. Lindgren, S. Li, et al., Common variants near MC4R are associated with fat mass, weight and risk of obesity, Nat Genet. 40(6), (2008), 768.

[16] W. Huang, Y. Sun, J. Sun, et al., Combined effects of FTO rs9939609 and MC4R rs17782313 on obesity and BMI in Chinese Han populations, Endocrine, 39(1), (2011), 69.

[17] D. Lv, D.D. Zhang, H. Wang, et al., Genetic variations in SEC16B, MC4R, MAP2K5 and KCTD15 were associated with childhood obesity and interacted with dietary behaviors in Chinese school-age population, Gene, 560(2), 2015, 149.

[18] L. Tao, Z. Zhang, Z. Chen, et al., A Common variant near the melanocortin 4 receptor is associated with low-density lipoprotein cholesterol and total cholesterol in the Chinese Han population, Mol Biol Rep, 39(6), (2012), 6487.

[19] J. Wang, H. Mei, W. Chen et al., Study of eight GWAS-identified common variants for association with obesity-related indices in Chinese children at puberty, Int $\mathrm{J}$ Obes (Lond) 36(4), (2012), 542.

\title{
Mối liên quan giữa đa hình đơn nucleotide rs17782313 của gen Melanocortin 4 Receptor với một số chỉ số nhân trắc của trẻ tiểu học bình thường và béo phì ở Hà Nội
}

\author{
Lê Thị Tuyết ${ }^{1}$, Trần Quang Bình ${ }^{2}$ \\ ${ }^{1}$ Khoa Sinh học, Truòng Đại học Su phạm Hà Nội, , 136 Xuân Thủy, Cà̀u Giáy, Hà Nội, Việt Nam \\ ${ }^{2}$ Viện Dinh duỡng Quốc gia, 48B Tăng Bạt Hổ, Hà Nội, Việt Nam
}

Tóm tắt: Thụ thể Melanocortin-4 (MC4R) có vai trò trong việc điều chỉnh lượng thức ăn và cân bằng năng lượng của cơ thể. Một số nghiên cứu trước đây cho thấy SNP rs17782313 của gen $M C 4 R$ có liên quan đáng kể với béo phì ở nhiều quần thể người. Tuy vậy, mối liên quan này ở người Việt Nam chưa được mô tả đầy đủ. Mục đích của nghiên cứu là đánh giá mối liên quan của rs17782313 với một số chỉ số nhân trắc và béo phì của trẻ tiểu học ở Hà Nội. Nghiên cứu bệnh chứng được tiến hành trên 559 trẻ em từ $6-11$ tuổi ( 278 trẻ béo phì và 281 trẻ bình thường). Tình trạng dinh dưỡng của trẻ được phân loại theo cả hai tiêu chẩn của IOTF 2000 và WHO 2007. Kết quả cho thấy ở nhóm trẻ bình thường, chỉ số z-score cân nặng theo tuổi cao nhất ở nhóm trẻ có kiểu gen $\mathrm{CC}$ và thấp nhất ở nhóm trẻ có kiểu gen $\mathrm{TT}$ (tương ứng là 0,11 và $-0,38, p=0,023)$. Ở nhóm trẻ béo phì, tỷ lệ eo hông thấp nhất ở nhóm có kiểu gen TT và cao nhất ở nhóm có kiểu gen $C C(0,93$ và $0,97, p=0,031)$. Kết quả này cho thấy biến thể rs 17782313 của gen $M C 4 R$ nhiều khả năng ảnh hưởng đến sự tăng khối lượng cơ thể và béo phì trung tâm ở trẻ Việt Nam.

Tù khoá: rs17782313, MC4R, béo phì, chỉ số nhân trắc, trẻ em Việt Nam. 